\title{
Bantuan Hukum terhadap Kaum Difabel Korban Tindak Pidana Upaya mewujudkan Acces to Justice
}

\author{
Anggun Malinda, Ekha Nurfitriana, dan M. Yasin Al Arif \\ Fakultas Hukum Universitas Islam Indonesia \\ J1. Tamansiswa No. 158 Yogyakarta \\ anggun_malinda@yahoo.com; ekha.nf@gmail.com; \\ yasinfhuii@gmail.com
}

\begin{abstract}
Legal aid and protection for disabled people are still difficult to get. Worse, there are not any legal institutions which protect them. The problems discussed in this research are: first, how is the issue of legal aid to disabled people as criminal victims and its challenges? Second, what kinds of legal aid that should be given to disabled people as criminal victims in order to bring access to justice? This was an empirical and normative legal research. The research findings show that: first, the advocacy of disabled people as the victims of violence has been handled by several LSM (Non-Governmental Organizations) in the field of legal aid. Most of the handled cases are discontinued in the middle of the process due to some issues regarding the legal aids, such as issues related to legal aid agencies, disabled victims, victims, and law enforcement apparatus. Second, the ideas suggested to legal aid agencies are to provide supervision from psychologists, translators, and special advocates to handle disabled victims. The ideas suggested to the police are to provide special investigating officers for disabled people, such as assigning police woman for rape and violence cases involving disabled woman victims; and in the judicial proceedings i.e. by one time investigation system in the investigation step in which judges review the victims' testimony based on police investigation report in the investigation step.
\end{abstract}

Keywords: Legal aid, disability, acces to justice

\begin{abstract}
Abstrak
Perlindungan dan bantuan hukum terhadap kaum difabel sampai saat ini masih sulit didapatkan bahkan tidak ada instrumen hukum secara khusus yang melindunginya. Masalah yang dikaji dalam penelitian adalah; pertama, bagaimana realitas pemberian bantuan hukum bagi kaum difabel korban tindak pidana dan kendala- kendalanya? Kedua, bantuan hukum seperti apa yang seharusnya diberikan kepada kaum difabel sebagai korban tindak pidana guna terwujudnya akses pada keadilan? Penelitian ini merupakan penelitian hukum empiris dan normatif. Hasil dari penelitian ini menyimpulkan: pertama, advokasi terhadap korban kekerasan kaum difabel telah ditangani oleh berbagai LSM dalam bidang bantuan hukum. Sebagian besar kasus yang ditangani, berhenti karena adanya kendala-kendala dalam proses bantuan hukumnya, antara lain kendala pada lembaga bantuan hukum; korban difabel; individu korban; dan aparat penegak hukum. Kedua, gagasan yang tawarkan pada lembaga bantuan hukumnya yaitu dengan menyediakan pendamping psikolog, penerjemah dan advokat khusus yang menangani korban difabel; pada pihak Kepolisian yaitu dengan menyediakan penyidik khusus untuk kaum difabel seperti Polisi Wanita terhadap perempuan difabel korban perkosaan dan kekerasan; dan dalam proses peradilan yaitu dengan sistem pemeriksaan 1 kali di tingkat penyidikan dimana hakim dalam proses peradilan memeriksa kesaksian korban berdasarkan berita acara pemeriksaan ditahap penyidikan.
\end{abstract}

Kata Kunci : Bantuan hukum, disabilitas, acces to justice 


\section{Pendahuluan}

Kaum difabel di Indonesia dari tahun ke tahun mengalami peningkatan kuantitasnya. Berdasarkan data Sensus Nasional Biro Pusat Statistik 2003 jumlah penyandang cacat di Indonesia sebesar 0,7\% dari jumlah penduduk sebesar 211.428.572 atau sebanyak 1.480.000 jiwa. ${ }^{1}$ Menurut Persatuan Penyandang Cacat Indonesia (PPCI), hingga pada tahun 2005 jumlah penyandang disabilitas ${ }^{2}$ di Indonesia mencapai 6 juta jiwa atau 3,11\%. Berdasarkan survey sensus penduduk Badan Pusat Statistik Republik Indonesia (BPSRI) pada tahun 2010 presentase jumlah penyandang disabilitas sebesar 8,76\% dari jumlah penduduk sebanyak 237.641.326 jiwa. $^{3}$ Ada lebih banyak perempuan penyandang disabilitas dibandingkan yang laki-laki (52,7\% berbanding 47,3\%). ${ }_{4}$ Dengan demikian peluang kaum difabel menjadi korban tindak pidana cukup besar. Hal itulah yang menjadi pencetus terjadinya kekerasan terhadap perempuan difabel.

Berdasarkan instrumen hukum, kaum difabel merupakan salah satu pihak yang berhak menerima bantuan hukum. Berdasarkan Pasal 5 Undang-Undang Nomor 16 Tahun 2011 tentang Bantuan Hukum menyatakan bahwa "yang menjadi penerima bantuan hukum adalah setiap orang atau kelompok orang miskin yang tidak dapat memenuhi hak dasar secara layak dan mandiri" ${ }^{5}$

Di dalam Surat Edaran Mahkamah Agung Nomor 10 Tahun 2010 tentang Pedoman Pemberian Bantuan Hukum Nomor 10/Bua.6/Hs/ SP/VIII/2010, tanggal 30 Agustus 2010, Pasal 19 dan Pasal 27 menetapkan, bahwa “orang-orang yang mendapat pelayanan dan bantuan hukum yaitu orang-orang yang tidak mampu membayar pengacara, khususnya perempuan, anak-anak, dan penyandang disabilitas".

Sekalipun dua instrumen hukum di atas telah mengatur, tetapi realitasnya yang terjadi di lapangan banyak dari mereka yang tidak mendapat bantuan hukum. Salah satunya dibuktikan dengan alasan pihak kepolisian tidak sensitif

${ }^{1}$ Sumber Sensus Nasional Biro Pusat Statistik tahun 2003.

${ }^{2}$ Kaum difabel dalam hal ini sama dengan istilah penyandang disabilitas.

${ }^{3}$ Sumber Hasil Sensus Penduduk 2010 BPS RI (Badan Pusat Statistik Republik Indonesia).

${ }^{4}$ Badan Pusat Statistik dan Departemen Sosial Buklet PMKS (Penyandang Masalab Kesejabteraan Sosial) Tabun 2006 (Berdasarkan Hasil Survei Sosial Ekonomi Nasional), hlm. 5.

${ }^{5}$ Lihat Pasal 5 Undang-Undang Nomor 16 Tahun 2011 tentang Bantuan Hukum. 
ketika menangani korban kaum difabel. Hal ini dibuktikan dengan adanya kasus yang terjadi dan korbannya penyandang disabilitas, tetapi perkaranya tidak dapat diproses. Kasus yang terjadi di Magelang, korbannya seorang mental retradasi yang berusia di atas 20 (dua puluh) tahun. Korban diperkosa oleh tetangganya sendiri. Pihak korban melaporkan ke kepolisian, tetapi kasus tersebut tidak bisa diproses dan berhenti di kepolisian karena korban ada kendala komunikasi, sehingga pihak kepolisian mengalami kesulitan untuk melanjutkan perkara tersebut. ${ }^{6}$

Dalam Undang-Undang Nomor 23 Tahun 2002 tentang Perlindungan Anak hanya mengakomodir umur anak berdasarkan umur kalender. Pasal 1 angka 1 Undang-Undang Nomor 23 Tahun 2002 tentang Perlindungan Anak menyatakan bahwa "Anak adalah seseorang yang belum berusia 18 (delapan belas) tahun, termasuk anak yang masih dalam kandungan".

Sementara usia kaum difabel berdasarkan kalender dikategorikan sebagai usia dewasa, padahal secara mental mereka masih belum dewasa dan masuk sebagai usia anak. Dengan demikian bantuan hukum bagi kaum difabel sekalipun mental mereka seperti anak, hal ini tidak dapat diproses di tingkat kepolisian. Sehingga perlindungan hukum dan hak-hak mereka menjadi terabaikan.

\section{Rumusan Masalah}

Berdasarkan permasalahan dan realita dalam perlindungan dan pemberian bantuan hukum terhadap kaum difabel yang telah diuraikan di atas, maka dirumuskan masalahnya sebagai berikut. Pertama, bagaimana realitas pemberian bantuan hukum terhadap kaum difabel korban tindak pidana dan kendalakendala yang dihadapi? Kedua, bantuan hukum seperti apa yang seharusnya diberikan kepada kaum difabel sebagai korban tindak pidana guna terwujudnya akses pada keadilan? 


\section{Tujuan Penelitian}

Penelitian ini bertujuan untuk: pertama, mengetahui dan menjelaskan tentang realitas pemberian bantuan hukum bagi kaum difabel korban tindak pidana dan kendala-kendalanya. Kedua, mengetahui dan menjelaskan bantuan hukum apa yang seharusnya diberikan kepada kaum difabel korban tindak pidana guna terwujudnya akses pada keadilan.

\section{Metode Penelitian}

Penelitian ini merupakan penelitian hukum empiris-normatif. Penelitian ini menggunakan pendekatan perundang-undangan ${ }^{7}$ dan pendekatan konseptual. Jenis data yang digunakan adalah data primer dan data sekunder. Data primer diperoleh melalui wawancara dengan pihak yang berkompeten dengan objek yang diteliti berupa data-data dari LKBH FH UII, SIGAB, RIFKA ANNISA, SAPDA yang bergerak dalam bidang pemberian bantuan hukum. Sedangkann data sekunder diperoleh melalui penelitian kepustakaan meliputi bahan hukum primer, sekunder, dan tersier. Bahkan hukum primer terdiri dari Undang-Undang Nomor 16 Tahun 2011 tentang Bantuan Hukum, Undang-Undang Nomor 4 Tahun 1997 tentang Penyandang Cacat, UndangUndang Nomor 19 Tahun 2011 tentang Pengesahan Conventionon the Rights Persons With Disabilities (Konvensi mengenai hak-hak penyandang disabilitas), dan Undang-Undang Nomor 39 Tahun 1999 tentang Hak Asasi Manusia. Bahan hukum sekunder berupa buku, jurnal, hasil penelitian yang terkait dengan kaum difabel. Bahan hukum tersier berupa Kamus Besar Bahasa Indonesia, kamus hukum, dan ensiklopedi. Analisis yang digunakan dalam penelitian ini adalah deskriptif kualitatif.

${ }^{7}$ Pendekatan perundang-undangan dipilih karena selain jenis penelitian ini masuk dalam penelitian hukum normatif dimana pendekatan perundang-undangan mutlak dijadikan sebagai salah satu pendekatan. Peter Mahmud Marzuki, Penelitian Hukum, Prenada Media, Jakarta, 2006, hlm. 5. 


\section{Hasil Penelitian dan Pembahasan}

\section{Konsep Bantuan Hukum}

Bantuan hukum dianggap sebagai bagian yang sangat penting untuk memberikan keadilan bagi masyarakat terutama mereka yang dianggap tidak mampu. Dalam pemberian bantuan hukum dikenal beberapa bentuk pelayanan, antara lain legal aid, legal assistance dan legal service. Ketiganya memiliki pengertian dan bentuk pelaksanaan yang berbeda. Legal aid merupakan pemberian bantuan hukum kepada seseorang yang dilakukan secara cuma-cuma dan dikhususkan kepada masyarakat yang tidak mampu. Legal aid secara konseptual merupakan bentuk upaya penegakan hukum dengan melakukan pembelaan terhadap kepentingan dan hak-hak asasi masyarakat miskin. ${ }^{8}$ Legal assistance merupakan pemberian bantuan hukum kepada seluruh kelompok masyarakat. Konsepsi legal assistance adalah memberikan bantuan hukum secara cuma-cuma kepada masyarakat miskin dan memberikan bantuan hukum dengan imbalan jasa kepada masyarakat yang mampu. Sedangkan legal service sesuai dengan maknanya adalah pelayanan hukum. Legal service hadir untuk memberikan pelayanan atau bantuan hukum kepada seluruh orang dengan tujuan untuk menjamin hak seluruh orang untuk mendapatkan nasehat hukum. ${ }^{9}$

Dalam ketentuan Pasal 1 angka 1 Undang-Undang Nomor 16 Tahun 2011 tentang Bantuan Hukum menyatakan bahwa "bantuan hukum adalah jasa hukum yang diberikan oleh Pemberi Bantuan Hukum secara cuma-cuma kepada Penerima Bantuan Hukum". ${ }^{10}$ Bantuan hukum dalam pengertiannya yang luas berarti upaya untuk membantu golongan yang tidak mampu dalam bidang hukum. Menurut Adnan Buyung Nasution, upaya ini mempunyai tiga aspek yang saling berkaitan, yaitu: pertama, aspek perumusan aturan-aturan hukum; kedua, aspek pengawasan terhadap mekanisme untuk menjaga agar aturan-

\footnotetext{
hlm. 344.

8 Yahya Harahap, Pembahasan dan Penerapan KUHAP, Edisi Kedua Cet. 11, Sinar Grafika, Jakarta, 2009,

9 Bambang Sunggono dan Aries Harianto, Bantuan Hukum dan Hak Asasi Manusia, Mandar Maju, Bandung, 1994, hlm. 10.

${ }^{10}$ Pasal 1 angka 1 Undang-Undang Nomor 16 Tahun 2011 tentang Bantuan Hukum
} 
aturan itu ditaati; dan ketiga, aspek pendidikan masyarakat agar aturan-aturan itu dihayati. ${ }^{11}$

Setidaknya ada tiga konsep atau jenis bantuan hukum di Indonesia, yaitu konsep bantuan hukum tradisional, bantuan hukum konstitusional maupun bantuan hukum struktural. Pertama, bantuan hukum tradisional, merupakan pelayanan hukum yang diberikan kepada masyarakat miskin secara individual. Bantuan hukum ini pasif dan pendekatannya sangat formal-legal, dalam arti melihat segala permasalahan hukum kaum miskin semata-mata dari sudut hukum yang berlaku. Penekanan dalam konsep ini lebih kepada hukum itu sendiri yang diandaikan netral sama rasa dan sama rata.

Kedua, bantuan hukum konstitusional, adalah bantuan hukum untuk rakyat miskin yang dilakukan dalam rangka usaha dan tujuan yang lebih luas, seperti menyadarkan hak-hak masyarakat miskin sebagai subyek hukum dan penegakan serta pengembangan nila-nilai hak asasi manusia sebagai sendi utama bagi tegaknya negara hukum. Sifat bantuan hukum ini lebih aktif artinya tidak hanya untuk individual tetapi juga ditujukan untuk kelompok-kelompok masyarakat secara kolektif. Pendekatan bantuan hukum ini selain formal-legal juga dengan jalan politik dan negosiasi.

Ketiga, konsep bantuan hukum struktural merupakan kegiatan yang bertujuan untuk menciptakan kondisi-kondisi bagi terwujudnya hukum yang mampu mengubah struktur yang timpang menuju ke arah struktur yang lebih adil. ${ }^{12}$ Masing-masing lembaga bantuan hukum tersebut kedudukan dan wewenangnya diatur tersendiri sehingga menyulitkan masyarakat dalam mempergunakan jasa hukum mereka. Para pemberi bantuan itu menetapkan sendiri-sendiri dalam melaksanakan tugas-tugasnya satu sama yang lain tidak ada koordinasinya. ${ }^{13}$ Pada dasarnya tujuan dari bantuan hukum adalah untuk memberikan perlindungan hukum bagi warga negaranya. Negara Republik Indoneisa memberikan perlindungan hukum yang sama bagi seluruh warga

\footnotetext{
${ }^{11}$ Bambang Sunggono dan Aries Harianto, Bantuan Hukum dan Hak. Asasi Manusia, Mandar Maju, Bandung, 2001, hlm. 7.

12Ibid., hlm. 26-30.

${ }_{13}$ Abdul Manan, Penerapan Hukum Acara Perdatadi Lingkungan Peradilan Agama, Kencana, Jakarta, 2005, hlm. 67
} 
negara Indonesia tanpa memandang dasar agama, ras/suku, keturunan, atau tempat lahirnya, dan latar belakang ekonomis, pendidikan, dan lain-lain. ${ }^{14}$

Kemudian, dalam Pasal 4 Undang-Undang Nomor 16 Tahun 2011 dijelaskan bahwa ruang lingkup dalam bantuan hukum meliputi bantuan hukum diberikan kepada penerima bantuan hukum yang menghadapi masalah hukum, bantuan hukum yang diberikan meliputi masalah hukum keperdataan, pidana,dan tata usaha negara baik litigasi maupun nonlitigasi dan bantuan hukum yang diberikan meliputi menjalankan kuasa, mendampingi, mewakili, membela, dan/atau melakukan tindakan hukum lain untuk kepentingan hukum penerima bantuan hukum.

Adapun pemberi bantuan hukum adalah lembaga bantuan hukum atau organisasi kemasyarakatan yang memberi layanan bantuan hukum berdasarkan Undang-Undang. ${ }^{15}$ Sedangkan penerima bantuan hukum adalah setiap orang atau kelompok orang miskin yang tidak dapat memenuhi hak dasar secara layak dan mandiri. ${ }^{16}$

Melihat rumusan definisi dari penerima bantuan hukum tersebut maka penyandang disabilitas atau kaum difabel dapat dikategorikan sebagai salah satu kelompok atau orang yang berhak menerima bantuan hukum. Sebab, penyandang cacat/penyandang disabilitas adalah setiap orang yang mempunyai kelainan fisik dan/atau mental, yang dapat mengganggu atau merupakan rintangan dan hambatan baginya untuk melakukan secara selayaknya, yang terdiri dari: penyandang cacat fisik; penyandang cacat mental; penyandang cacat fisik dan mental. ${ }^{17}$

Pemakaian kata difabel yang dimulai sejak 1997 dapat dimaksudkan sebagai kata eufemisme, yaitu penggunaan kata yang memperhalus kata atau istilah yang digunakan sebelumnya. Tetapi secara luas istilah difabel digunakan sebagai salah satu usaha untuk mengubah persepsi dan pemahaman masyarakat bahwa setiap manusia diciptakan berbeda dan seorang difabel hanyalah sebagai

\footnotetext{
${ }^{14}$ Zainuddin Ali, Sosiologi Hukum, Sinar Grafika, Jakarta, 2005, hlm. 101-102.

${ }^{15}$ Pasal 1 angka 3 Undang-Undang Nomor 16 Tahun 2011 tentang Bantuan Hukum.

${ }^{16}$ Pasal 1angka 2 Undang-Undang Nomor 16 tahun 2011 tentang Bantuan Hukum.

${ }^{17}$ Pasal 1angka 1 Undang-Undang Nomor 4 tahun 1997 tentang Penyandang cacat.
} 
seseorang yang memiliki perbedaan kondisi fisik dan dia mampu melakukan segala aktivitas dengan cara dan pencapaian yang berbeda. ${ }^{18}$

Selain itu, dampak yang ditimbulkan dari seseorang yang menyandang disabilitas, akan berdampak ke beberapa masalah, diantaranya: (1) Masalah fisik. Kecacatan yang diderita seseorang dapat mengakibatkan gangguan kemampuan fisik untuk melakukan sesuatu perbuatan atau gerak tertentu yang berhubungan dengan kegiatan hidup sehari-hari. (2) Psikologis. Akibat kecacatan dapat mengganggu kejiwaan/mental seseorang, sehingga seseorang menjadi rendah diri atau sebaliknya menghargai dirinya terlalu berlebihan, mudah tersingung, kadang-kadang agresif, pesimistis, labil, sulit untuk mengambil keputusan dan sebagainya. (3) Sosial ekonomi. Masalah ini tergambar dengan adanya kehidupan penyandang cacat tubuh yang pada umumnya berada di bawah garis kemiskinan. Hal ini disebabkan oleh rendahnya pendapatan. (4) Pendidikan. Karena kecacatan fisiknya, hal ini sering menimbulkan kesulitan khususnya anak umur sekolah. Mereka memerlukan perhatian khusus baik dari orangtua maupun guru disekolah. Sebagian besar kesulitan ini juga menyangkut transportasi antara tempat tinggal ke sekolah, serta kesulitan mempergunakan alat- alat sekolah, dan (5) vokasional. Kecacatan yang diderita seseorang dapat mengakibatkan gangguan kemampuan fisik untuk melakukan sesuatu seperti keterampilan tertentu, karena mereka kehilangan satu atau lebih anggota badannya, sehingga mengganggu aktivitasnya. ${ }^{19}$

\section{Memahami Acces to Justice (Akses menuju keadilan)}

Pengertian akses menuju keadilan adalah kesempatan atau kemampuan setiap warga negara tanpa membedakan latar belakangnya (ras, agama, keturunan, pendidikan, atau tempat lahirnya) untuk memperoleh keadilan melalui lembaga peradilan. ${ }^{20}$ Akses menuju keadilan adalah hak setiap orang untuk mendapatkan akses memperoleh keadilan melalui lembaga peradilan yang merupakan hak asasi manusia. Mengenai akses menuju keadilan, Joshua

\footnotetext{
${ }^{18}$ Mansour Fakih, Panggil Aku Difabel dalam Jalan Lain Manifesto Intelektual Organik, Pustaka Pelajar, Yogyakarta, 2002, hlm. 304.

${ }^{19} \mathrm{http}: / /$ wahdadupetro.blogspot.com/2012/10/makalah-tentang-penyandang-cacat.html,diakses pada tanggal 4Mei2013.

${ }^{20}$ Satjipto Rahardjo, Sisi-Sisi Lain dari Hukum di Indonesia, Buku Kompas, Jakarta, 2003, hlm. 177
} 
Rozenberg berpendapat: Few of usgiveita second thought. We assume justice will some how be available, on tab, when ever weneedit, but when thet imecomestoen force our rights many of us will find it very difficult-if not down right impossible to obtain true justice from hecourts. ${ }^{21}$

The Conventionon The Rightsof Personswith Disabilities dalam Pasal 13 dijelaskan secara eksplisit mengenai akses terhadap keadilan yang menyatakan bahwa: 1. Negara menjamin bahwa penyandang disabilitas bisa mendapatkan kesempatan dan perlakuan yang sama dalam peradilan. Negara menjamin bahwa setiap aturan peradilan harus disesuaikan dengan keadaan penyandang disabilitas sehingga bisa berperan penuh dalam semua tahap peradilan dan persidangan misalnya sebagai saksi; 2 . Negara akan memberikan pelatihan untuk memahami penyandang disabilitas bagi mereka yang bekerja di lembaga peradilan seperti polisi dan pegawai penjara. 22

Sebagai negara hukum (rechtstaat) sebagaimana bunyi Pasal 1 ayat (3) Undang-Undang Dasar 1945 yang menyatakan “Negara Indonesia adalah negara hukum", maka negara harus menjamin persamaan setiap orang di hadapan hukum serta melindungi hak asasi manusia.

Selanjutnya, dalam rangka menegakkan keadilan, ada beberapa asas yang perlu dipatuhi guna memperoleh acces to justice. Namun, menurut Djohansjah ${ }^{23}$ asas-asas ini tidak tercantum secara eksplisit dalam Undang-Undang No. 8 Tahun 1981 tentang Hukum Acara Pidana, tetapi justru terdapat pada Konsideran dan Penjelasan Umum KUHAP, khususnya dalam angka 3 bahwa: asas yang mengatur perlindungan terhadap keluhuran harkat serta martabat manusia yang telah diletakkan di dalam undang-undang tentang ketentuan-ketentuan Pokok Kekuasaan Kehakiman, yaitu UU No. 14 Tahun 1970 harus ditegakkan dalam dan dengan undang-undang ini. Asas-asas tersebut antara lain: a. Perlakuan yang sama atas diri setiap orang di hadapan hukum dengan tidak mengadakan

${ }^{21}$ Joshua Rozenberg, The Search For Justice An Anotamy od the Law, Hodder and Stoughton Ltd, 194, hlm. 171. Yang terjemahannya adalah" Beberapa dari kita memberikan suatu permikiran bahwa keadilan telah ada dan tersedia apabila kita membutuhkannya, akan tetapi apabila tiba waktunya untuk melaksanakan hak-hak kita, kita akan mendapatkan kesulitan- kesulitan atau tidak mendapatkannya sama sekali, untuk memperoleh keadilan yang benar dari lembaga peradilan"

${ }^{22}$ Terjemahan Pasal 13 Conventionon The Rightsof Personswith Disabilities (CRPD)

${ }^{23}$ Djohansjah, "Akses Menuju Keadilan", Pelatihan Hak Asasi Manusia Untuk Jejaring Komisi Yudisial RI Bandung, 30 Juni-3 Juli 2010. 
pembedaan perlakuan; b. Setiap orang yang disangka, ditangkap, ditahan, didakwa di pengadilan, wajib dianggap tidak bersalah sampai adanya putusan pengadilan yang menyatakan kesalahannya dan memperoleh kekuatan hukum tetap (presumption of innocence); c. Setiap orang yang tersangkut perkara wajid diberi kesempatan memperoleh bantuan hukum yang semata-mata diberikan untuk melaksanakan kepentingan pembelaan.

\section{Realitas Pemberian Bantuan Hukum bagi Kaum Difabel Korban Tindak Pidana}

Advokasi terhadap korban kekerasan kaum difabel telah ditangani oleh berbagai LSM dalam bidang bantuan hukum, diantaranya LSM SIGAB (Sasana Integrasi dan Advokasi Difabel) yang bergerak di bidang bantuan hukum khususnya terhadap kaum difabel. LKBH FH UII (Lembaga Konsultasi dan Bantuan Hukum Fakultas Hukum Universitas Islam Indonesia) yang bergerak di bidang bantuan hukum. LSM Rifka Annisa WCC (Women Crisis Center) yang bergerak dalam bidang pengembangan sumber daya untuk penghapusan kekerasan terhadap perempuan, LSM SAPDA (Sentra Advokasi Perempuan Difabel dan Anak), dan lain-lainnya.

Dari data yang diperoleh dalam studi lapangan, salah satunya adalah korban perkosaan. Kasus perkosaan terhadap korban difabel antara lain, kasus di Magelang, korban yang menderita mental retardasi ringan dan layu 1 tangan berusia 25 tahun yang dilakukan oleh paman korban yang juga penderita low vision dimana korban melaporkan kepada orang tuanya setelah hamil 3 bulan, korban juga dapat menunjukkan pelaku, serta dapat memberikan kesaksian. Dari pihak keluarga menginginkan adanya tes DNA sebagai pembuktian tetapi sebelum dilakukan tes DNA pelaku mengakui perbuatannya. Namun, dalam penanganannya proses berhenti sampai kepolisian karena kasus dicabut oleh keluarga akibat intervensi dari perangkat desa dengan mekanisme penyelesaian secara kekeluargaan. ${ }^{24}$

${ }^{24}$ Kasus yang pernah ditangani oleh SAPDA 
Korban yang menderita mental retardasi dengan hambatan komunikasi berusia di atas 20 tahun yang diperkosa oleh tetangganya. Korban datang ke SAPDA untuk meminta bantuan terhadap kasus tersebut. Pihak SAPDA melaporkan ke pihak kepolisian. Dalam kasus ini korban tidak bisa bersaksi karena hambatan komunikasi, serta pada saat itu juga mengalami kesulitan komunikasi sehingga kasus tersebut berhenti karena tidak bisa diproses.

Kasus yang ditangani oleh berbagai lembaga bantuan hukum lainnya antara lain kasus yang terjadi di Boyolali yang korbannya menderita retardasi mental berumur18 tahun yang diperkosa olah kakeknya sendiri. Pelakunya dibebaskan karena korbannya tidak mengalami trauma. Saat dipersidangan, korban justru mendekati kakeknya karena korban tersebut sehari-harinya hidup dengan kakeknya sendiri. Kemudian hakim menstigma bahwa hal tersebut tidak terjadi trauma karena korban dekat dengan pelaku. Pada hal korban mengalami gangguan pada mentalnya yang pemikirannya tidak dapat mencapai pemikiran orang dewasa. ${ }^{25}$

Kasus perkosaan di Yogyakarta yang dialami oleh seseorang yang menderita slow learner berusia 22 tahun yang diperkosa oleh tetangganya sendiri, sehingga korban hamil. Pada saat dilakukan proses pemeriksaan, korban dapat menunjuk dan mengidentifikasi pelaku, selain itu korban juga dapat menceritakan kronologi kejadian. Namun, yang menjadi kendala adalah saksinya juga seorang slow learner. Kelemahan akademik utama yang dialami oleh slow learner adalah membaca, berbahasa, danmemori, sosial, dan perilaku. Akhirnya kasus tersebut tidak dapat diproses. ${ }^{26}$

Kasus yang terjadi di Solo yang menjadi korban seorang tunanetra yang berprofesi sebagai tukang pijit diperkosa oleh orang yang menggunakan jasa tukang pijit tersebut. Kasus tersebut dilaporkan oleh istri pelaku pada pihak kepolisian. Kasus ini ditangani oleh SIGAB, kemudian melakukan pendampingan terhadap korban. Namun, kasus ini tidak dapat diproses karena kurangnya bukti. ${ }^{27}$

\footnotetext{
${ }^{25}$ Kasus yang pernah ditangani oleh Lembaga Bantuan Hukum SIGAB

${ }^{26}$ Kasus yang pernah ditangani oleh Lembaga Bantuan Hukum SAPDA

${ }^{27}$ Kasus yang pernah ditangani oleh SIGAB
} 
Kasus pemerkosaan yang dialami oleh seorang perempuan tunarungu dan tunawicara yang datang ke lembaga bantuan hukum LKBH, tetapi karena korban tersebut kesulitan dalam berkomunikasi dan tidak adanya saksi-saksi dan alat bukti, sehingga pihak LKBH kesulitan untuk melanjutkan perkara tersebut. ${ }^{28}$

Ada juga korban tindak pidana kekerasan. Pada kasus yang korbannya penderita Paraplegia yang terjadi di Sleman, yang mengalami kekerasan fisik, dipukuli oleh suami, uang dan materi dirampas, ditinggal selingkuh, dan diperkosa (KDRT) yang pelakunya adalah suaminya sendiri. Korban melaporkan kekerasan tersebut ke pihak kepolisian. Tapi, kasus tersebut berhenti di kepolisian karena adanya paksaan dari pihak keluarga untuk mencabut laporan tersebut. $^{29}$

Banyak sekali kasus-kasus korban tindak pidana yang korbannya seorang kaum difabel, sering didiskriminasikan oleh lembaga bantuan hukum, khususnya di kepolisian. Banyak pelaku yang bebas dan perkara tersebut tidak dapat berjalan. Sehingga perlu adanya suatu gagasan baru mengenai bantuan hukum untuk mengurangi diskriminasi tersebut dan menjunjung asas equality before the law.

\section{Kendala Pemberian Bantuan Hukum bagi Kaum Difabel Korban Tindak Pidana}

Berdasarkan kasus-kasus yang terjadi di atas, pada kenyataannya banyak kasus-kasus yang berhenti dalam penanganannya. Dari realitas pemberian bantuan hukum terhadap korban tindak pidana yang korbannya adalah seorang kaum difabel, terdapat beberapa kendala yang dialami baik kendala pada lembaga bantuan hukum, kendala pada korban, dan kendala pada aparat penegak hukum antara lain sebagai berikut: Pertama, kendala pada Lembaga Bantuan Hukum. Kendala yang terjadi yaitu tidak adanya pendamping psikolog maupun penerjemah khusus difabel terutama pada korban difabel yang

\footnotetext{
${ }^{28}$ Wawancara dengan Kiki Purwaningsih, Konsultan Hukum pada hari Senin, 30 April 2013 di LKBH FH UII.

${ }^{29}$ Kasus yang pernah ditangani oleh Lembaga Bantuan Hukum SAPDA.
} 
menderita retardasi mental, tuna rungu, tuna wicara, slow learner. Kendala lain yang dialami oleh lembaga yang menangani korban difabel, seperti tidak adanya saksi yang melihat peristiwa kekerasan yang dialami korban, serta kurangnya alat bukti juga menjadi hambatan dalam memproses ke ranah hukum. Jika terjadi perkosaan biasanya seorang perempuan akan segera membersihkan diri karena merasa tubuhnya kotor telah disentuh oleh orang lain. Hal itu tentu saja menghilangkan bukti perkosaan yang terjadi pada dirinya. Begitu juga pada peristiwa KDRT, korban merasa malu dan tidak penting melakukan visum et repertum luka-luka akibat kekerasan yang dialaminya. Karena kurangnya saksi maupun bukti yang ada sehingga dari pihak lembaga bantuan hukum tidak dapat melanjutkan proses tersebut ke tahap selanjutnya, yaitu tahap laporan kepada pihak kepolisian. ${ }^{30}$

Kedua, kendala pada Korban Difabel, antara lain: a) Korban dianggap tidak konsisten dalam menceritakan kronologi kejadian.Pada korban tunagrahita/mental retarded sering tidak dapat mengungkapkan peristiwa kekerasan atau perkosaan yang dialaminya secara jelas dan konsisten. Hal ini menyebabkan pihak aparat hukum sering kesulitan atas kesaksian korban. Akibatnya, kesaksian korban yang tidak konsisten sering disimpulkan bahwa korban telah berbohong; b) Usia korban (ketidak sesuaian antara usia kalender dan usia mental). Berdasarkan kalender, umur korban termasuk dalam kategori dewasa, namun tidak pada mentalnya. Secara mental, korban belum dewasa sehingga aparat penegak hukum sering mengesampingkan kesaksian yang diungkapkan oleh korban; c) Kendala dari Individu Korban. Pada saat terjadi kekerasan terhadap penyandang disabilitas, korban tidak dapat melawan dan tidak mampu membela diri karena keterbatasan yang ia miliki, baik keterbatasan gerak, keterbatasan bicara, maupun katerbatasan intelegensia (pada tuna grahita). Hal tersebut yang menyebabkan korban disabilitas tidak dapat melakukan perlawanan. Selain itu, korban disabilitas tidak memahami situasi (tindak pidana) yang dialami (untuk kondisi tertentu seperti Mental Retarded/ keterbelakangan mental dengan kemampuan intelegensi rendah). Hal ini terjadi

30 Wawancara dengan berbagai lembaga bantuan hukum di Yogyakarta, 26 April 2013. 
khususnya pada tuna grahita atau mental retarded. Sebagian besar dari mereka menganggap perlakuan kekerasan atau perkosaan terhadapnya adalah bentuk dari kasih sayang pelaku terhadapnya; d) Korban tidak memahami akibat fisik, sosial, dan psikologi. Biasanya korban tidak mampu memahami akibat dari kekerasan dan perkosaan yang dialaminya. Korban tidak dapat mengantisipasi perbuatan pelaku karena korban tidak mengetahui apa yang telah pelaku lakukan itu merupakan bentuk kekerasan. Pada diri korban tidak ada respon emosi pada umumnya hanya korban merasa sakit secara fisik. Bahkan saat mendapat perlakuan kekerasan, korban tidak menggambarkan ekspresi muka emosi, dan bahkan hanya ekspresi emosi positif (tertawa atau tersenyum) sebagai akibat dari ketidak mampuannya secara kognitif dalam memahami peristiwa kekerasan yang dialami; e) Korban tidak dapat memahami hak yang dimiliki. Penyandang disabilitas mempunyai keterbatasan pengetahuan dan informasi yang berkaitan dengan hak-hak mereka. Hal ini membuat penyandang disabilitas tidak memahami apa yang menjadi hak mereka ketika terjadi kekerasan dan perkosaan; f) Sistem administrasi peradilan yang tidak aksesibel. Sistem administrasi di kepolisian sangat berbelit-belit sehingga menyebabkan kesulitan dalam melaporkan perkara.

Ketiga, kendala Pada Aparat Penegak Hukum. Realitas yang terjadi pada proses bantuan dan pelayanan hukum terhadap kaum difabel selama ini adalah ketidaksiapan aparat penegak hukum dalam menangani kasus-kasus yang korbannya difabel dan sering dihentikannya, bahkan menolak kasus dan melakukan pembiaran atas kasus tindak pidana terhadap kaum difabel. Hal ini terjadi karena aparat penegak hukum belum memahami mengenai bentuk kecacatan beserta kebutuhan pada masing-masing korban, dan tidak memiliki keterampilan khusus untuk melakukan penanganan terhadap perempuan difabel, retardasimental, netra, rungu, wicara maupun jenis difabel lainnya. Selain itu, aparat penegak hukum belum menganggap difabel sebagai warga negara yang mempunyai hak yang sama di hadapan hukum, dengan kata lain tidak menjunjung asas equality before the law. ${ }^{31}$ Selain itu terdapat banyak 
kelemahan-kelemahan di dalam mencari keadilan bagi kaum difabel dalam tingkat penyidikan oleh pihak kepolisian, yaitu: a) Penolakan pelaporan kasus di kepolisian. Hal ini sering terjadi penolakan saat lembaga bantuan hukum mendampingi korban untuk melakukan pelaporan kepihak kepolisian, dikarenakan kesulitan dari pihak kepolisian dalam proses pemeriksaan korban karena korban susah berkomunikasi dan tidak adanya alat-alat bukti; b) Rendahnya pengetahuan aparat penegak hukum dan kepolisian terhadap isu difabel termasuk haknya. Pihak kepolisian kurang sensitif dalam melihat korban seorang kaum difabel. Karena kaum difabel seringkali di diskriminasikan di kalangan masyarakat. Selain itu Rendahnya training bagi petugas kepolisian, pengadilan, lembaga bantuan hukum lainnya untuk mengerti penyandang disabilitas dan kebutuhan spesifik dalam mengakses keadilan serta bagaimana menyediakan akomodasi yang diperlukan; c) Tidak tersedianya sarana pendukung seperti petunjuk braile, penerjemah bahasa isyarat. Hal inilah yang menjadikan pihak kepolisian menjadi kesulitan dalam menangani kaum difabel, terutama pada saat proses pemeriksaan; d) Penolakan kaum difabel sebagai saksi. Seringkali kesaksian kaum difabel ditolak, karena pada saat memberikan kesaksian, mereka tidak konsisten dalam menjekaskan kronologi kejadian. Dan juga keyakinan bahwa orang dengan masalah kejiwaan tidak bisa diakui kesaksiannya; e) Undang-undang yang tidak berpihak dan tidak melindungi kaum difabel. Dalam Undang-Undang Nomor 23 Tahun 2002 tentang Perlindugan Anak hanya mengakomodir berdasarkan usia kalender. Jadi pihak kepolisian akan sangan kesulitan ketika akan menentukan pasal apa yang akan dijatuhi kepada pelaku. Karena belum adanya undang-undang yang mengakomidir inilah banyak para pelaku yang bisa bebas dan perkara tidak dapat diproses.

\section{Gagasan Bantuan Hukum Untuk Kaum Difabel Korban Tindak Pidana Guna Terciptanya Acces to Justice}

Berdasarkan realitas pemberian bantuan hukum terhadap kaum difabel korban tindak pidana dan juga kendala-kendala yang dihadapi di berbagai 
Lembaga Bantuan Hukum dan pihak kepolisian, maka penulis membuat gagasan baru untuk memberikan perlindungan dan hak-hak kaum difabel, antara lain:

Pertama, gagasan untuk Lembaga Bantuan Hukum. Seharusnya di dalam lembaga bantuan hukum harus mempunyai pendamping psikolog untuk semua jenis difabel. Tujuannya untuk mengetahui karakter dari masing-masing korban tindak pidana secara psikologi. Setelah mengetahui karakter korban difabel, kemudian pendamping psikolog tersebut berusaha untuk mengurangi trauma yang terjadi pada korban atas kejadian yang dialaminya. Dengan demikian, korban dapat menjelaskan kronologi kejadian secara konsisten dan jelas.

Selain itu juga, dalam lembaga bantuan hukum harus ada seorang penerjemah untuk kaum difabel, khususnya difabel jenis slow learner, tuna rungu dan wicara, dan retardasi mental. Hal ini bertujuan agar pihak lembaga bantuan hukum yang melakukan penanganan terhadap kasus tersebut memahami apa yang disampaikan oleh korban berdasarkan kemampuan penerjemah dalam menerjemahkan bahasa atau isyarat yang diungkapkan oleh korban. Misalnya, dalam kasus yang korbannya menderita mental retardasi dengan hambatan komunikasi berusia di atas 20 tahun yang diperkosa oleh tetangganya. Korban datang ke SAPDA untuk meminta bantuan terhadap kasus tersebut. Pihak SAPDA melaporkan ke pihak kepolisian. Dalam kasus ini korban tidak bisa bersaksi karena hambatan komunikasi, serta pada saat itu juga mengalami kesulitan komunikasi sehingga kasus tersebut berhenti karena tidak bisa diproses. Berdasarkan kasus tersebut, dengan adanya penerjemah, sehingga memudahkan korban berkomunikasi dengan pihak lembaga bantuan hukum.

Selain itu juga, dalam lembaga bantuan hukum harus adanya advokat khusus bagi difabel korban tindak pidana. Dengan adanya advokat khusus, akan sangat membantu pihak lembaga bantuan hukum dalam menangani perkara karena advokat tersebut sudah mempunyai pengalaman sehingga sangat mudah dalam membantu difabel korban tindak pidana.

Kedua, gagasan untuk Pihak Kepolisian. Dalam kasus tindak pidana yang korbannya seorang perempuan difabel, seharusnya yang melakukan pemeriksaan terhadap korban adalah seorang polisi wanita (Polwan). Menurut Satjipto Rahardjo menilai bahwa kehadiran wanita dalam jajaran Polri akan 
dapat mengubah wajah pemolisian, yaitu dari yang bersifat keras menjadi bergaya lembut. Sehingga sangat tepat jika Polwan ditempatkan pada bidang tugas yang khusus menangani kasus yang korbannya seorang perempuan kaum difabel, terutama kasus kekerasan maupun perkosaan. Polisi wanita lebih memahami kondisi psikis dari perempuan korban tindak pidana. Karena tindak pidana perkosaan sering menimpa kaum wanita, maka tepat jika penyidikannya dilakukan oleh seorang Polisi Wanita terutama untuk mengorek keterangan korban, mengingat korban umumnya mengalami goncangan dan trauma sangat berat, maka diperlukan terapi yang tepat dan terus-menerus agar korban pulih seperti sediakala. ${ }^{32}$

Selain itu, seharusnya pihak kepolisian juga mempunyai pendamping psikolog terhadap korban tindak pidana semua jenis difabel. Tujuannya untuk mengetahui karakter dari masing-masing korban tindak pidana secara psikologi. Setelah mengetahui karakter korban difabel, kemudian pendamping psikolog tersebut berusaha untuk mengurangi trauma yang terjadi pada korban atas kejadian yang dialaminya. Dengan demikian, korban dapat menjelaskan kronologi kejadian secara konsisten dan jelas.

Gagasan lain dalam penanganan kaum difabel di tingkat kepolisian harus adanya seorang penerjemah untuk kaum difabel, khususnya difabel jenis slow learner, tunarungu dan wicara, dan retardasi mental. Hal ini bertujuan agar pihak kepolisian yang melakukan penanganan terhadap kasus tersebut memahami apa yang disampaikan oleh korban berdasarkan kemampuan penerjemah dalam menerjemahkan bahasa atau isyarat yang diungkapkan oleh korban. Dan agar perkara tersebut dapat diproses dan diajukan ke persidangan. Misalnya dalam kasus perkosaan di Yogyakarta yang dialami oleh seseorang yang menderita Slow Learner berusia 22 tahun yang diperkosa oleh tetangganya sendiri, sehingga korban hamil. Pada saat dilakukan proses pemeriksaan, korban dapat menunjuk dan mengidentifikasi pelaku, selain itu korban juga dapat menceritakan kronologi kejadian. Yang menjadi kendala adalah saksinya juga seorang slow learner. Akhirnya kasus tesebut tidak dapat diproses. Berdasarkan kasus tersebut

32http://groups.yahoo.com/group/wanita-muslimah/message/3156, diakses pada tanggal 5 Mei 2013. 
dengan adanya seorang pendamping psikolog dan penerjemah dapat mengurangi kendala yang dihadapai selama proses pemeriksaan.

Pihak kepolisian seharusnya memandang seorang difabel korban tindak pidana terutama yang menderita retardasi mental maupun slow learner yang berusia di atas 18 tahun berdasarkan usia mental, bukan berdasarkan usia kalender. Sehingga polisi dapat menggunakan ketentuan dari Undang-Undang Nomor 23 Tahun 2002 tentang Perlindungan Anak dalam menangani kasus tersebut.

Ketiga, gagasan dalam Proses Peradilan. Seluruh proses peradilan kasus perkosaan merupakan penderitaan bagi korban. Pada saat penyelidikan dan penyidikan, korban harus menceritakan peristiwa yang telah menimbulkan trauma. Pada saat sidang pengadilan, korban kembali mengalami penderitaan karena harus memberikan kesaksian dan dipertemukan dengan terdakwa/pemerkosa selaku orang yang paling dibenci. Selesai persidangan, korban kadang mendapat stigma negatif dari masyarakat, dan korban masih mengalami penderitan, misalnya pelaku dibebaskan atau dihukum ringan. ${ }^{33}$

Di dalam proses persidangan, seharusnya kaum difabel yang menjadi korban tindak pidana ini tidak perlu dijadikan sebagai saksi lagi dengan kata lain korban hanya diperiksa pada tahap penyidikan saja atau mengalami satu kali pemeriksaan. Hakim cukup menjadikan BAP (Berita Acara Pemeriksaan) sebagai bukti untuk meyakinkan hakim. Hal ini dikerenakan kaum difabelini harus dikhususkan di dalam penanganannya, berbeda dengan korban tindak pidana yang korbannya umum. Sehingga kaum difabel tidak menjadi korban dalam sistem. Karena mereka telah menjadi korban pada saat diperkosa atau kekerasan. Setelah itu mereka menjadi korban kedua kalinya ditingkat kepolisian yang prosesnya sulit.

\section{Penutup}

Berdasarkan hasil analisis dan pembahasan yang telah diuraikan di atas, maka dapat diperoleh dua kesimpulan sebagai berikut: pertama, advokasi terhadap korban kekerasan kaum difabel telah ditangani oleh berbagai LSM

33http://groups.yahoo.com/group/wanita-muslimah/message/3156, diakses pada tanggal 5 Mei 2013. 
dalam bidang bantuan hukum. Sebagian besar kasus yang ditangani, berhenti karena adanya kendala-kendala dalam proses bantuan hukumnya antara lain kendala pada Lembaga Bantuan Hukum dengan tidak adanya advokat khusus, pendamping psikolog maupun penerjemah; kendala pada korban difabel antara lain korban dianggap tidak konsisten dalam menceritakan kronologi kejadian, usia korban (ketidak sesuaian antara usia kalender dan usia mental), kendala dari individu korban, korban tidak memahami akibat fisik, sosial, dan psikologi, korban tidak dapat memahami hak yang dimiliki, sistem administrasi peradilan yang tidak aksesibel. Terakhir kendala pada aparat penegak hukum, antara lain adanya penolakan pelaporan kasus di kepolisian, karena korban susah berkomunikasi dan tidak adanya alat-alat bukti, rendahnya pengetahuan aparat hukum dan kepolisian terhadap isu difabel termasuk haknya, tidak tersedianya sarana pendukung seperti petunjuk braille, penerjemah bahasa isyarat, penolakan kaum difabel sebagai saksi dan lain-lain.

Kedua, gagasan bantuan hukum terhadap kaum difabel korban tindak pidana guna terciptanya acces to justice antara lain dibagi menjadi gagasan pada Lembaga Bantuan Hukum yaitu dengan menyediakan pendamping psikolog, penerjemah dan advokat khusus yang menangani korban difabel; gagasan pada pihak kepolisian yaitu dengan menyediakan penyidik khusus untuk kaum difabel seperti Polisi Wanita terhadap perempuan difabel korban perkosaan dan kekerasan, pendamping psikolog dan penerjemah; dan terakhir gagasan dalam proses peradilan yaitu dengan sistem pemeriksaan 1 kali ditingkat penyidikan dimana hakim dalam proses peradilan meriksa kesaksian korban berdasarkan berita acara pemeriksaan di tahap penyidikan. Hal ini ditujukan agar korban tidak menjadi korban kedua, atau bahkan ketiga (korban sistem) dalam proses peradilannya.

\section{Daftar Pustaka}

Ali, Zainuddin, Sosiologi Hukum, Sinar Grafika, Jakarta, 2005.

Fakih, Mansour, Panggil Aku Difabel dalam Jalan Lain Manifesto Intelektual Organik, Pustaka Pelajar, Yogyakarta, 2002. 
Harahap, Yahya, Pembahasan dan Penerapan KUHAP, Edisi Kedua Cet. 11, Sinar Grafika, Jakarta, 2009.

Marzuki, Peter Mahmud, Penelitian Hukum, Prenada Media, Jakarta, 2006.

Manan, Abdul, Penerapan Hukum Acara Perdata di Lingkungan Peradilan Agama, Kencana, Jakarta, 2005.

Rahardjo, Satjipto, Sisi-Sisi Lain dari Hukum di Indonesia, Buku Kompas, Jakarta, 2003.

Rozenberg, Joshua, The Search For Justice An Anotamy od the Law, Hodder and Stoughton Ltd, 1994.

Sunggono, Bambang, Bantuan Hukum dan Hak Asasi Manusia, Mandar Maju, Bandung, 2001.

Sunggono, Bambang dan Aries Harianto, Bantuan Hukum dan Hak Asasi Manusia, Mandar Maju, Bandung, 1994.

Djohansjah, "Akses Menuju Keadilan", Pelatihan Hak Asasi Manusia Untuk Jejaring Komisi Yudisial RI Bandung, 30 Juni-3 Juli 2010.

Sumber Sensus Nasional Biro Pusat Statistik tahun 2003.

Sumber Hasil Sensus Penduduk 2010 BPS RI (Badan Pusat Statistik Republik Indonesia).

Badan Pusat Statistik dan Departemen Sosial Buklet PMKS (Penyandang Masalah Kesejahteraan Sosial) Tahun 2006 (Berdasarkan Hasil Survei Sosial Ekonomi Nasional).

Data kasus yang ditangani oleh LSM SAPDA (sentra Advokasi Perempuan Difabel dan Anak)

Convention The Rightsof Personswith Disabilities (CRPD)

Undang-Undang Dasar 1945

Undang-Undang Nomor 16 tahun 2011 tentang Bantuan Hukum

Undang-Undang Nomor 16 tahun 2011 tentang Bantuan Hukum.

Undang-Undang Nomor 4 tahun 1997 tentang Penyandang cacat.

http://groups.yahoo.com/group/wanita-muslimah/message/3156, diakses pada tanggal 5 Mei 2013.

http://groups.yahoo.com/group/wanita-muslimah/message/3156,diakses pada tanggal 5 Mei 2013.

http:/ / wahdadupetro.blogspot.com/2012/10/makalah-tentang-penyandangcacat.html, diakses pada tanggal 4 Mei 2013. 